\title{
Neoadjuvant or Definitive Chemoradiation for Locoregional Esophageal Cancer and its Outcome at South Egypt Cancer Institute (Retrospective Study)
}

\author{
MOHAMED T. AMIN, M.Sc.*; DALIA MOHAMED, M.D.*; ABEER AMIN, M.D.**; \\ SAMIA ABD EL-KAREEM, M.D.** and MAHA EL-NAGGAR, M.D.**
}

The Departments of Radiotion Oncology, South Egypt Cancer Institute* and Clinical Oncology, Faculty of Medicine**, Assiut University

\begin{abstract}
Background: It is well known about esophageal carcinoma, the aggressive and invasive nature, in addition to the poor outcome. The experience of south Egypt cancer institute was to review the locally advanced esophageal carcinoma, treated by chemo radiation either followed by surgery or not, and their outcome.
\end{abstract}

Aim of Study: In this study, we evaluate the efficacy of chemoradiation as a definitive or preoperative treatment.

Patients and Methods: During the period June 2008, till June 2014,55 patients with locally advanced esophageal cancer were reviewed for treatment with preoperative or definitive concurrent chemo radiation, at Radiation Oncology Department, South Egypt Cancer Institute, Assiut University. Statistical analysis of data was done by the statistical package for the social science (SPSS) version 20

Results: Out of 55 patients, 26 patients were included for definitive chemo radiation (dCRT). And 29 patients were included for neoadjuvant chemo radiation (nCRT). Squamous cell carcinoma (SqCC) represented in $72.7 \%$ of patients. Patients had disease stage II and III (32.7\% and 67.3\%) respectively. Median total radiation dose was 50.4 Gy over 28 fractions. Cisplatin+Fluorouracil regimen was received by $30(54.5 \%)$ patients, while Paclitaxel+Carboplatin regimen was received by $25(45.5 \%)$ patients. Overall response $(\mathrm{CR}+\mathrm{PR})$ was observed in $34(72.3 \%)$ patients, while disease progression occurred in $5(10.6 \%)$ patients and $17 \%$ (8 patients) had stable disease. The disease stage at diagnosis was a significant factor affecting clinical response. Out of 29 patients at neoadjuvant group, 18 patients (62\%) underwent surgery, without major postoperative complications. Complete pathological response (no residual cancer cells) was observed in 6 (33\%) patients. Median OS for dCRT and nCRT was 21 and 39 months respectively, it was in favor for nCRT group with no statistical significance $(p$-value $=0.20)$. Median PFS for dCRT and nCRT was 16 and 18 months respectively, with no statistical significance $(p$-value $=0.363)$. Disease stage at diagnosis and clinical response after radiotherapy were very highly significant factors affecting patients' overall survival

Correspondence to: Dr. Mohamed T. Amin, The Department of Radiotion Oncology, South Egypt Cancer Institute, Assiut University and disease progression survival $(p$-value $=0.014)$. Overall grade $\geq 3$ toxicity 26 events was observed in $16(29.0 \%)$ of the patients.

Conclusion: Neoadjuvant chemo radiation followed by surgery is considered as a standard care management for patients with resectable locally advanced esophageal carcinoma and fit for surgery. For patients with inoperable disease or unfit for surgery, definitive chemo radiation is accepted treatment option. The used chemotherapy regimens, Cisplatin/Fluorouracil and Paclitaxel/Carboplatin, are tolerable in most patients with acceptable toxicity profile; and with no differences between two regimens.

Key Words: Esophageal carcinoma-Definitive concurrent chemo radiation-Neoadjuvant chemotherapy.

\section{Introduction}

ESOPHAGEAL cancer is considered the eighth most common cancer worldwide and the sixth most common cause of death from cancer [1,2]. At 2013 more than 1100 cases were diagnosed in Egypt, that according to the latest publication of national cancer registry program [1]. Esophageal cancer is aggressive and invasive in nature, more than $50 \%$ of patients have unresectable disease at time of diagnosis [3] . Preoperative chemo radiotherapy followed by surgery, was introduced to downstage the primary tumor, thus increasing the chance of resectability and eliminating micro metastases $[4$, 5]. In 1992 Nygaard et al., were the first group reported that preoperative chemotherapy and radiotherapy prolonged patient survival [6]. After that several studies showing survival advantages for preoperative chemo radiation followed by surgery over surgery alone [7,9]. A meta-analysis was conducted and reported a significant survival benefit for preoperative chemoradiotherapy followed by surgery in patients with esophageal squamous cell carcinoma $[\mathbf{1 0 , 1 1 ]}$. The potential curative surgery is valid only for approximately $25 \%$ of patients 
[12]. In the rest of the patients with no metastatic disease, definitive concurrent chemo radiotherapy (CRT) is considered the standard treatment. Definitive CRT for esophageal cancer has not changed much in the past 23 years since the landmark RTOG 8501 trial [13]. Herskovic et al reported in 1992 that cisplatin and 5-fluorouracil (5FU) added concurrently to radiation (RT) improved local control, decreased metastases, and prolonged survival [13] The updated outcome publication from RTOG 8501 trial reported a median survival of 14.1 months for the CRT-treated patients. This regimen was the standard of care [14]. Another chemotherapy regimen (weekly paclitaxel and carboplatin concurrently with RT) has been established as the preferred neoadjuvant treatment option for both squamous and adenocarcinoma of the esophagus after the long term results of CROSS trial have been published [15], and several studies have explored the use of this regimen in the definitive setting as well [16-20].

In our study; we reviewed the experience of South Egypt Cancer Institute in patients with locally advanced esophageal carcinoma treated by chemoradiation either followed by surgery or not; the efficacy and tolerability of different chemotherapy regimens used; and their outcome.

\section{Patients and Methods}

We retrospectively studied 55 patients with locally advanced esophageal carcinoma who presented to south Egypt Cancer Institute at Assiut university since June 2008 to June 2014; they were treated either with preoperative chemoradiation followed by surgery or definitive concurrent chemo radiation.

For all patients, the medical records had reviewed for patients' characteristics: Age and sex of the patient, patient's performance status (PS) according to the eastern cooperative oncology group (ECOG) scale, the presenting symptoms; regarding dysphagia, weight loss, vomiting, chest pain and cough. Dysphagia was recorded according to dysphagia grading scale in European organization for research and treatment of cancer quality of Life questionnaire (EORTC QLQ-C30).

Disease characteristics:Tumor site, histopathological diagnosis, type and grade, as reported in the endoscopic biopsy, disease staging, according to the 7 th edition of the tumor, node, metastasis [TNM] staging system of the American joint committee on cancer (AJCC).

Treatment data: Patients were categorized according to intention of treatment into: Definitive chemo radiation group (dCRT), including patients received definitive concurrent chemo radiation. This group includes patients with unresectable disease (based on CT imaging), and patients unfit for surgery, and neoadjuvant chemo radiation group (nCRT), including patients with resectable disease and fit for surgery. These patients received neoadjuvant concurrent chemo radiation, and then planned for surgery.

Treatment plan: All patients received chemo radiation, and after 4-6 weeks they were evaluated for response using response evaluation criteria in solid tumors (RECIST; version 1.1) for response definitions.

Radiation therapy: Was delivered using linear accelerator with photon energy of 6-15 MV, conventional fractionation $(1.8-2 \mathrm{GY})$ five fractions per week, for (5.6-6 weeks), aimed (50.4 Gy$60 \mathrm{GY})$. The target volumes; for conventional 2D planning (16 patients, $29 \%$ ); $5 \mathrm{~cm}$ in cranial and caudal directions to the visualized lesion; to cover sub-mucosal spread, $1.5-2.5 \mathrm{~cm}$ in lateral directions. Customized blocks were used to shape the treatment fields and to spare normal lung tissues. For conformal 3D planning (39 patients, 71\%); GTV: gross tumor+involved lymph nodes, CTV: Tumor+3$5 \mathrm{~cm}$ longitudinal $+0.5-1 \mathrm{~cm}$ circumferential, Involved nodes $+0.5-1 \mathrm{~cm}$ in all directions, PTV: $\mathrm{CTV}+0.5-1 \mathrm{~cm}$. Elective nodal coverage; upper tumors (above the carina); periesophageal, mediastinal and supraclavicular, lower tumors (below the carina); periesophageal, mediastinal, perigastric and celiac lympnodes. The field arrangement; for conventional 2D planning; anterior-posterior (AP/PA) fields were used up to 40-45 Gy, to minimize dose to the lungs then three fields (anterior open field and 2 anterior oblique wedged fields) were used; to spare the spinal cord. For conformal 3D planning; 3-5 beams were used; provided by DVH for GTV, PTV and normal organs at risk.

Chemotherapy: Two regimens were used and recorded (Cisplatin+Fluorouracil) Cisplatin:100 $\mathrm{mg} / \mathrm{m}^{2}$ IV on day 1 , Fluorouracil: $1000 \mathrm{mg} / \mathrm{m}^{2} \mathrm{IV}$ infusion over 1-2 hours on days 1-4. Cycle every 28 days; two cycles with radiation followed by two cycles of consolidation without radiation (weeks 1, 5, 8, 11). The second regimen (Paclitaxel +Carboplatin); Paclitaxel: $50 \mathrm{mg} / \mathrm{m}^{2}$ IV on Day 1,Carboplatin: AUC 2 IV on Day 1.The regimen was repeated weekly for 5 weeks, with radiation.

Toxicity: Acute toxicity; treatment related toxicities within the first 6 months after finishing the treatment were recorded according to common 
terminology criteria for adverse events (CTCAE; version 3.0). Late toxicity; treatment related late toxicities after 6 months of starting the treatment were recorded according to CTCAE (version 3.0). Any palliative procedure against dysphagia was reported.

Follow-up: All patients were followed-up by CT scans and endoscopy every 3-6 months in first year, then 6 months in second year, and annually after then. Follow-up period calculated from first day of diagnosis till last follow-up visit or death.

Overall survival (OS) was measured from the first day of diagnosis to the time of death or the date of last follow-up. Progression free survival (PFS) was calculated from the first day of diagnosis to the time of first disease progression.

Statistical analysis: Statistical analysis of data was done by the statistical package for the social science (SPSS) version 20. Descriptive statistics was used as median, mean, number and percentage. Kaplan-Meier test used for survival analysis, and Log rank test was used to evaluate the significant differences between variables. Chi-square test was used to evaluate the relation between variables and treatment response. $p$-value was double sided and considered significant if was $\leq 0.05$.

\section{Results}

55 patients with esophageal cancer were retrospectively reviewed. 26 patients were planned for definitive chemo radiation group, out of them; 11 patients with unresectable disease and 15 patients were medically unfit for major surgery. And 29 patients were included for neoadjuvant chemo radiation group, out of them 18 patients underwent surgery, 5 patients showed progressive disease after chemo radiation, 4 patients were medically unfit after chemo radiation and 2 patients refused surgery.

Patient's characteristics: The median age at time of diagnosis was 61 years. Males presented $63.6 \%$ of the patients' population while females presented $36.4 \%$. According to ECOG scale; all our patients in the study between grade 1 and 2 . The most common presenting complaint was dysphagia $(94.5 \%)$, followed by significant weight loss $(85.4 \%)$ (Table 1).

Disease characteristics: Regarding site; the tumor was found most frequently in lower esophagus in $52.7 \%$ of patients. Squamous cell carcinoma (SqCC) was the most common pathology (72.7\%). Most of the lesions were moderately differentiated carcinomas $(60 \%)$. All patients were with disease stage II and III ( $32.7 \%$ and $67.3 \%$ respectively). Node positive disease (N1-3) was diagnosed in $63.6 \%$ of patients (Table 2 ).

Table (1): Patient characteristics in neoadjuvant (nCRT) and definitive chemoradiation (dCRT) treatment groups at time of presentation.

\begin{tabular}{|c|c|c|c|}
\hline & \multicolumn{3}{|c|}{ Patient Characteristics } \\
\hline & $\begin{array}{l}\text { dCRT Group } \\
\quad(\mathrm{n}=26)\end{array}$ & $\begin{array}{l}\text { nCRT Group } \\
\quad(\mathrm{n}=29)\end{array}$ & $\begin{array}{c}\text { All Groups } \\
(\mathrm{n}=55)\end{array}$ \\
\hline \multicolumn{4}{|l|}{ Age: } \\
\hline Median & 67 years & 57 years & 61 years \\
\hline Range & 43-71 years & 38-70 years & $38-71$ years \\
\hline \multicolumn{4}{|l|}{ Sex: } \\
\hline Male & $16(61.5 \%)$ & $19(65.5 \%)$ & $35(63.6 \%)$ \\
\hline Female & $10(38.5 \%)$ & $10(34.5 \%)$ & $20(36.4 \%)$ \\
\hline \multicolumn{4}{|l|}{$\begin{array}{l}\text { ECOG } \\
\text { performance }\end{array}$} \\
\hline $\begin{array}{l}\text { status: } \\
\text { I }\end{array}$ & $2 \%)$ & $16(552)$ & $21(38,2 \%)$ \\
\hline II & $21(80.8 \%)$ & $13(44.8 \%)$ & $34(61.8 \%)$ \\
\hline \multicolumn{4}{|c|}{$\begin{array}{l}\text { Dysphagia } \\
\text { grading scale: }\end{array}$} \\
\hline Grade 1 & $1(3.8 \%)$ & $11(37.9 \%)$ & $12(21.8 \%)$ \\
\hline Grade 2 & $10(38.5 \%)$ & $15(51.7 \%)$ & $25(45.5 \%)$ \\
\hline Grade 3 & $11(42.3 \%)$ & $3(10.3 \%)$ & $14(25.5 \%)$ \\
\hline Grade 4 & $4(15.4 \%)$ & $0(0.0 \%)$ & $4(7.3 \%)$ \\
\hline $\begin{array}{l}\text { Significant } \\
\text { weight loss }\end{array}$ & $19(73.1 \%)$ & $11(37.9 \%)$ & $30(54.5 \%)$ \\
\hline
\end{tabular}

Table (2): Disease characteristics in neoadjuvant (nCRT) and definitive chemoradiation treatment (dCRT) groups at time of presentation.

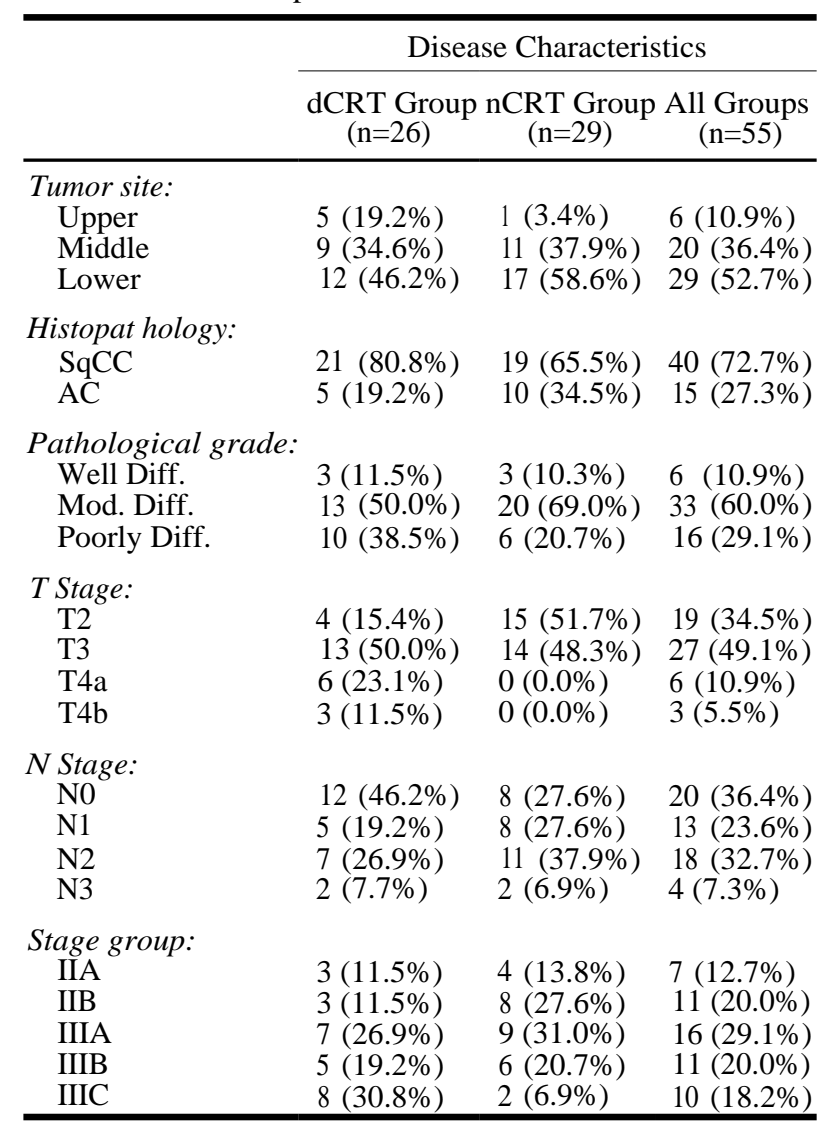


Clinical response after chemo radiation and factors affecting the response: After chemoradiation therapy 18 patients in definitive dCRT groups and 29 patients in nCRT group was available for endoscopic evaluation and histopathological examination done revealed dCRT group and complete response in 7 patients $(38.9 \%)$ and 16 patients (55. $2 \%)$ and partial response in with overall response 5 patients $(27.8 \%)$ and 6 patients $(20.7 \%)$ respectively. The overall response rate was $72.3 \%$ and progressive disease was on $17.2 \%$ of the patients all of them in the nCRT arm (Fig. 1) (Table 3).
Table (3): Treatment clinical response evaluation after chemoradiation therapy in neoadjuvant (nCRT) and definitive chemoradiation treatment (dCRT) groups.

\begin{tabular}{|c|c|c|c|}
\hline & $\begin{array}{l}\text { dCRT Group } \\
(\mathrm{n}=18)\end{array}$ & $\begin{array}{l}\text { nCRT Group } \\
(\mathrm{n}=29)\end{array}$ & $\begin{array}{c}\text { All Groups } \\
(\mathrm{n}=47)\end{array}$ \\
\hline Overall Response & $12(66.7 \%)$ & $22(75.9 \%)$ & $34(72.3 \%)$ \\
\hline $\begin{array}{l}\text { Complete Response } \\
\text { (CR) }\end{array}$ & $7 \quad(38.9 \%)$ & $16(55.2 \%)$ & $23(48.9 \%)$ \\
\hline $\begin{array}{l}\text { Partial Response } \\
\text { (PR) }\end{array}$ & $5 \quad(27.8 \%)$ & $6 \quad(20.7 \%)$ & $11(23.4 \%)$ \\
\hline $\begin{array}{l}\text { Stable Disease } \\
\text { (SD) }\end{array}$ & $6 \quad(33.3 \%)$ & $2 \quad(6.9 \%)$ & $8 \quad(17.0 \%)$ \\
\hline $\begin{array}{l}\text { Progressive Disease } \\
\text { (PD) }\end{array}$ & $\begin{array}{ll}0 & (0.0 \%)\end{array}$ & $5 \quad(17.2 \%)$ & $5 \quad(10.6 \%)$ \\
\hline
\end{tabular}

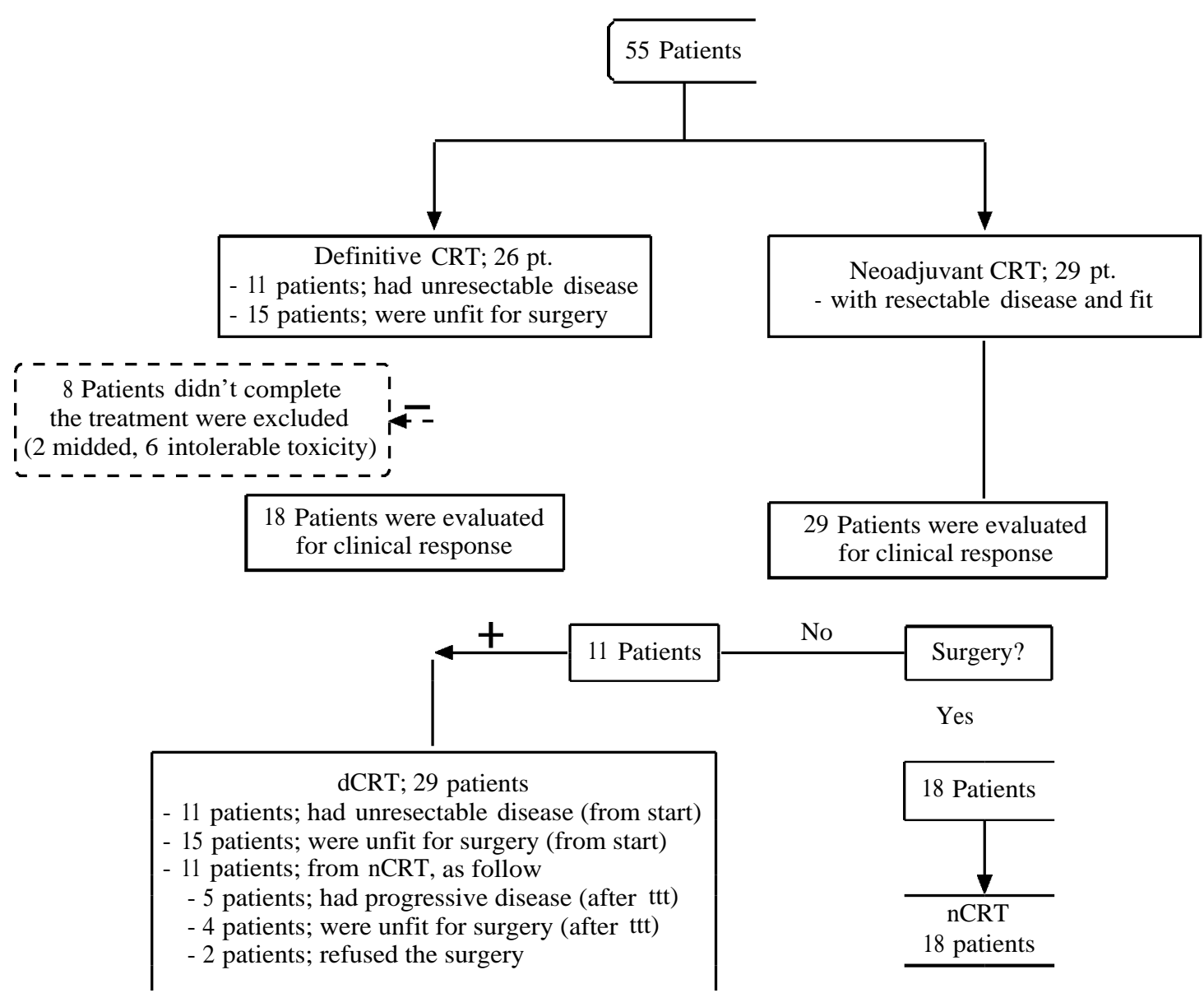

Fig. (1): Algorithm representing the patient's treatment groups neoadjuvant (nCRT) group 29 patients and definitive chemoradiation treatment (dCRT) group 26 patients.

Out of all the studied factors, only the disease stage group at diagnosis was a significant factor affecting clinical response (Table 4).

\section{Toxicity:}

Acute toxicity: Radiation therapy was tolerable for the majority of patients with mild to moderate complaints; this improved with sup- portive medical treatment, and did not require treatment interruption. Overall grade $\geq 3$ toxicity 26 events was observed in $16(29.0 \%)$ of the patients. Grade $\geq 3$ toxicity occurred in 9 $(34.6 \%)$ patients in dCRT group, versus 7 $(24.1 \%)$ in nCRT group. The most common events were neutropenia, followed by esophagitis (Table 5). 
Table (4): A multivariate analysis of factors affecting clinical response showed that stage of the disease was the most significant factor $(p$-value $=0.025)$.

\begin{tabular}{|c|c|c|c|c|c|c|}
\hline \multirow{2}{*}{$\begin{array}{l}\text { Variable } \\
\text { Age: }\end{array}$} & \multicolumn{2}{|c|}{ Number CR } & \multicolumn{3}{|c|}{ PR SD PD } & \multirow[t]{2}{*}{$\begin{array}{c}p- \\
\text { value }\end{array}$} \\
\hline & & & & & & \\
\hline$<60$ years & 21 & 11 & 4 & 4 & 2 & 0.911 \\
\hline 60 years & 26 & 12 & 7 & 4 & 3 & \\
\hline \multicolumn{7}{|l|}{ ECOG PS: } \\
\hline I & 21 & 11 & 5 & 3 & 2 & 0.959 \\
\hline II & 26 & 12 & 6 & 5 & 3 & \\
\hline \multicolumn{7}{|l|}{ Tumor site: } \\
\hline Upper & 5 & 2 & 1 & 1 & 1 & 0.953 \\
\hline Middle & 17 & 7 & 5 & 3 & 2 & \\
\hline Lower & 25 & 14 & 5 & 4 & 2 & \\
\hline \multicolumn{7}{|c|}{ Histo - pathology: } \\
\hline $\mathrm{SqCC}$ & 33 & 16 & 8 & 6 & 3 & 0.945 \\
\hline $\mathrm{AC}$ & 14 & 7 & 3 & 2 & 2 & \\
\hline \multicolumn{7}{|c|}{ Pathological grade: } \\
\hline Well Diff. & 6 & 5 & 1 & 0 & 0 & 0.283 \\
\hline Mod. Diff. & 29 & 14 & 8 & 5 & 2 & \\
\hline Poorly Diff. & 12 & 4 & 2 & 3 & 3 & \\
\hline \multicolumn{7}{|l|}{ Stage group: } \\
\hline IIA & 7 & 7 & 0 & 0 & 0 & 0.025 \\
\hline IIB & 11 & 6 & 4 & 1 & 0 & \\
\hline IIIA & 13 & 6 & 1 & 4 & 2 & \\
\hline IIIB & 9 & 4 & 3 & 0 & 2 & \\
\hline IIIC & 7 & 0 & 3 & 3 & 1 & \\
\hline \multicolumn{7}{|l|}{ Radiation dose: } \\
\hline $50.4 \mathrm{~Gy} / 28 \mathrm{fr}$ & 28 & 16 & 6 & 2 & 4 & 0.116 \\
\hline $60 \mathrm{~Gy} / 30 \mathrm{fr}$ & 19 & 7 & 5 & 6 & 1 & \\
\hline \multicolumn{7}{|c|}{ Chemotherapy regimen: } \\
\hline $\mathrm{Cis} / \mathrm{Fu}$ & 25 & 11 & 6 & 5 & 3 & 0.886 \\
\hline Taxel/Carbo & 22 & 12 & 5 & 3 & 2 & \\
\hline
\end{tabular}

Table (5): Grade >3 3 Acute toxicity events after chemoradiation therapy in neoadjuvant (nCRT) and definitive chemoradiation treatment (dCRT) groups.

\begin{tabular}{|c|c|c|c|}
\hline & $\begin{array}{l}\text { dCRT Group } \\
(\mathrm{n}=26)\end{array}$ & $\begin{array}{l}\text { nCRT Group } \\
(\mathrm{n}=29)\end{array}$ & $\begin{array}{l}\text { All Groups } \\
(\mathrm{n}=55)\end{array}$ \\
\hline Esophagitis & $4(15.4 \%)$ & $3(10.3 \%)$ & $7 \quad(12.7 \%)$ \\
\hline Anorexia & $1(3.8 \%)$ & $1(3.4 \%)$ & $2(3.6 \%)$ \\
\hline Fatigue & $2(7.7$ & $1(3.4 \%)$ & $3 \quad(5.5 \%)$ \\
\hline Neutropenia & $6(23.1 \%)$ & $7(24.1 \%)$ & $13(23.6 \%)$ \\
\hline Diarrhea & $0(0.0 \%)$ & $1(3.4 \%)$ & $1 \quad(1.8 \%)$ \\
\hline
\end{tabular}

Late toxicity: During follow-up; 10 events of grade >3 3 late toxicity were recorded in $7(12.7 \%)$ patients. Severe esophageal stenosis that required endoscopic dilatation occurred in $6(10.9 \%)$ patients.

Progression free survival (PFS): Median PFS for dCRT and nCRT was 16 and 18 months respectively, with no statistical significance ( $p$-value $=0.363$ ). As observed in OS; disease stage at diagnosis and clinical response after radiotherapy are very highly significant factors affecting disease progression (Fig. 2) (Table 6).

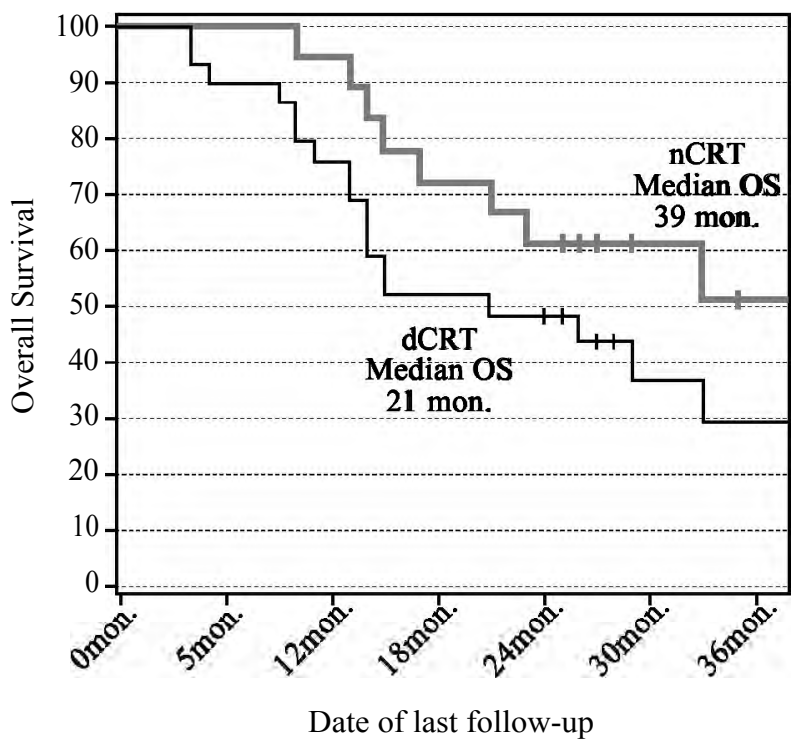

Fig. (2): Overall survival in neoadjuvant (nCRT) and definitive chemoradiation treatment (dCRT) groups in 36 months follow-up was 39 and 21 months respectively, with no statistical significance ( $p$-value $=0.20)$.

Table (6): A multivariate analysis of factors affecting progression free survival (PFS), showed that stage of the disease and response to treatment were the significant factor affect the PFS.

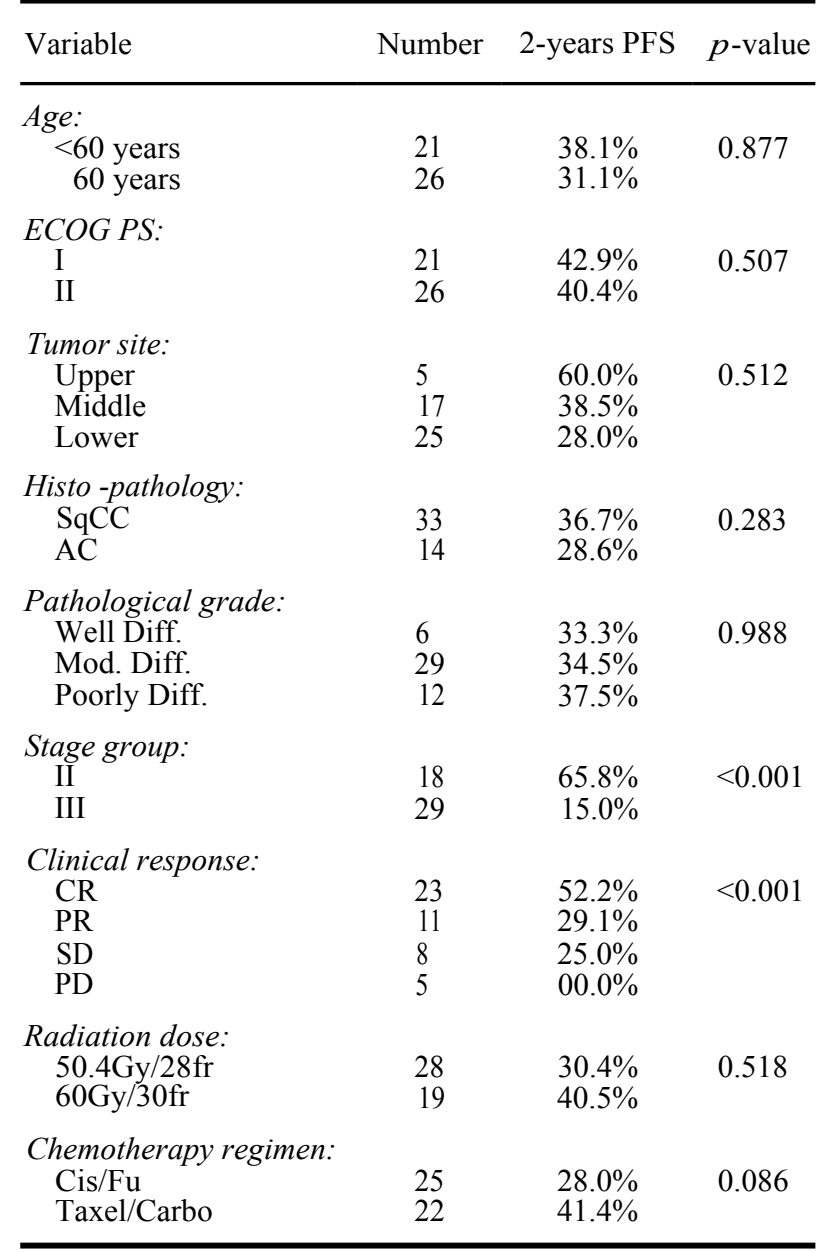


Survival analysis: Median OS for dCRT and nCRT was 21 and 39 months respectively, with no statistical significance $(p$-value $=0.20)($ Fig. 3) . Overall survival was in favor for nCRT group, at 2 and 3 years, but without statistical significance.

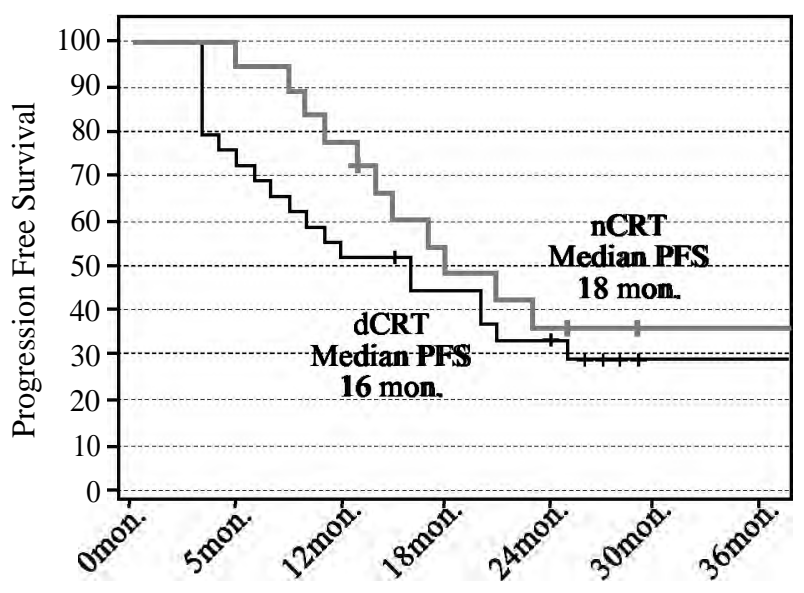

Date of disease progression in months

Fig. (3): Progression Survival in neoadjuvant (nCRT) and definitive chemoradiation treatment (dCRT) groups in 36 months follow-up was 18 and 16 months respectively, with no statistical significance $(p$-value $=0.363$ ).

Table (7): A multivariate analysis of factors affecting Overall survival (OS) showed that pathological grade, stage of the disease, clinical response to treatment were the most significant factors affecting OS.

\begin{tabular}{|c|c|c|c|}
\hline Variable & Number & 2-years OS & $p$-value \\
\hline $\begin{array}{l}\text { Age: } \\
<60 \text { years } \\
60 \text { years }\end{array}$ & $\begin{array}{l}21 \\
26\end{array}$ & $\begin{array}{l}57.1 \% \\
50.0 \%\end{array}$ & 0.158 \\
\hline $\begin{array}{l}\text { ECOG PS: } \\
\text { I } \\
\text { II }\end{array}$ & $\begin{array}{l}21 \\
26\end{array}$ & $\begin{array}{l}61.9 \% \\
46.2 \%\end{array}$ & 0.077 \\
\hline $\begin{array}{l}\text { Tumor site: } \\
\text { Upper } \\
\text { Middle } \\
\text { Lower }\end{array}$ & $\begin{array}{l}5 \\
17 \\
25\end{array}$ & $\begin{array}{l}40.0 \% \\
58.8 \% \\
52.0 \%\end{array}$ & 0.630 \\
\hline $\begin{array}{l}\text { Histo - patholog. } \\
\text { SqCC } \\
\text { AC }\end{array}$ & $\begin{array}{l}33 \\
14\end{array}$ & $\begin{array}{l}60.6 \% \\
35.7 \%\end{array}$ & 0.078 \\
\hline $\begin{array}{l}\text { Pathological g } \\
\text { Well Diff. } \\
\text { Mod. Diff. } \\
\text { Poorly Diff. }\end{array}$ & $\begin{array}{l}6 \\
29 \\
12\end{array}$ & $\begin{array}{l}50.0 \% \\
62.1 \% \\
33.3 \%\end{array}$ & 0.022 \\
\hline $\begin{array}{l}\text { Stage group: } \\
\text { II } \\
\text { III }\end{array}$ & $\begin{array}{l}18 \\
29\end{array}$ & $\begin{array}{l}72.2 \% \\
41.4 \%\end{array}$ & 0.014 \\
\hline $\begin{array}{l}\text { Clinical respon } \\
\text { CR } \\
\text { PR } \\
\text { SD } \\
\text { PD }\end{array}$ & $\begin{array}{l}23 \\
11 \\
8 \\
5\end{array}$ & $\begin{array}{l}73.9 \% \\
54.4 \% \\
33.3 \% \\
00.0 \%\end{array}$ & $<0.001$ \\
\hline $\begin{array}{c}\text { Radiation dose } \\
50.4 \mathrm{~Gy} / 28 \mathrm{fr} \\
60 \mathrm{~Gy} / 30 \mathrm{fr}\end{array}$ & $\begin{array}{l}28 \\
19\end{array}$ & $\begin{array}{l}53.6 \% \\
52.6 \%\end{array}$ & 0.960 \\
\hline $\begin{array}{l}\text { Chemotherapy } \\
\text { Cis/Fu } \\
\text { Taxel/Carbo }\end{array}$ & $\begin{array}{l}25 \\
22\end{array}$ & $\begin{array}{l}44.0 \% \\
62.5 \%\end{array}$ & 0.149 \\
\hline
\end{tabular}

Disease stage at diagnosis and clinical response after radiotherapy are very highly significant factors affecting patients' survival (Table 7) (Fig. 4). Poorly differentiated carcinomas were associated with lower survival.

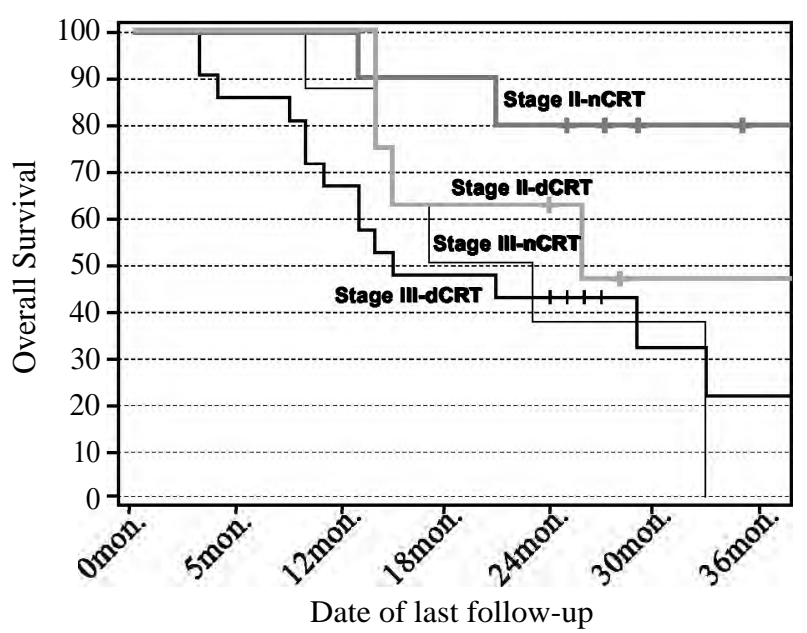

Fig. (4): Overall Survival in neoadjuvant (nCRT) and definitive chemoradiation treatment (dCRT) groups according to disease stage.

\section{Discussion}

In an attempt to improve the outcome of patients with locally advanced esophageal carcinoma multiple studies suggest that no added benefit from surgery after chemo radiation among the complete responder $[\mathbf{5 , 1 5}]$. Others tried alternative regimens of chemotherapy rather than the standard one [19] We retrospectively studied 55 patients presented at South Egypt Cancer Institute whether treated as neoadjuvant chemo radiation followed by surgery or definitive chemo radiation using two different regimens.

The median age of our patients was 61 years with age ranged from 38 to 71 years. This figure is comparable to that reported by Conroy et al., [21] and Bedenne et al., [22] (Median age was 60 and 59 respectively). However, other studies were able to study a group of older patients, with median age of 69 years, the age ranged from 46 to 82 years $[18,23]$. And that mostly due to better general condition, better available supportive treatment in the developed country rather than our developing one.

As regard pathological types, $\mathrm{SqCC}$ was the most common among our studied cases as it diagnosed in $72.7 \%$ followed by AC that was diagnosed in $27.3 \%$. This figure is slightly more than that reported by Ben Alexander Fulton [23] (64\% SqCC, $36 \% \mathrm{AC}$ ) and less than that reported by Conroy et al., [21] (86\% SqCC, 14\% AC). We noticed no difference as regard response to treatment among 
the two pathological types and regard the overall survival although the Sqce had better OS but it was not statistically significant, it may requires further studies contain larger number to more accurate results especially among complete responder.

As reported by Kim et al., that almost $50 \%$ of patients presented by locally advanced disease at diagnosis, and only $60 \%$ of them are resectable [24]. At our study Almost 2/3 of our patients were stage III (67.3\%), and the rest were stage II (32.7\%). Haisley et al., [25], in their retrospective study, showed patients with stage II or III esophageal carcinoma with percentage of $30 \%$ and $62 \%$, respectively. Also, El-Sayed et al., [26] studied definitive chemoradiation in patients with locally advanced esophageal carcinoma with percentage of $33 \%$ and $67 \%$, respectively.

After the end of treatment course, treatment response was assessed in all patients using complementary CT and endoscopic ultra sonographic guided biopsy. $46.7 \%$ of our patients showed complete response and $24.4 \%$ partial response. Among the studied factors that affect the treatment response, only the disease stage at diagnosis was a significant factor affecting clinical response.

That is comparable to Conroy et al., [21], as they reported $43 \%$ with complete response and $22 \%$ with partial response. Also, Song et al documented treatment responses as general in $73 \%$ of their patients [31]

However, we reported better response rates than reported in Noronha et al., [20] and Voncken et al., [27], as they reported rates of $49 \%$ and $48 \%$, respectively. These numbers could be explained by; more patients with advanced stage in Noronha et al., (T4 patients were 53\%), While in Voncken et al., more patients with adenocarcinoma (75\%), and only $72 \%$ were evaluated after the end of treatment [27]. However our estimated CR was less than Ilson et al., who reported 35 out of 51 patients (69\%) with CR, it might be as a result of more aggressive protocol using induction chemotherapy followed by chemo radiation then surgery [28] .

After using multivariate analysis, only the clinical response after chemo radiotherapy were highly significant factors affecting patients' survival, as Rizvi et al., said [29]. So we need further studies including larger number and longer period for follow-up are required to determine who get benefit by further surgery. As Steyerberg et al., mentioned that if we can avoid the morbidity and mortality of additional surgery after achievement a complete response by chemo radiation [30]. Recent analysis have been shown that the addition of esophagectomy to chemoradiotherapy in locally advanced esophageal squamous cell carcinomaprobably delays loco regional relapse, but didn't significantly improve OS, and may be associated with higher treatment-related mortality [31]

The median OS in our study was 29 months and 3-year OS was 38\%. The median PFS was 17 months and 3-year PFS was 32\%. These results were comparable to Song et al., they reported median OS of 23 months (3-year OS=37\%), and median PFS of 21 months (3-year PFS $=31 \%$ ), in spite of using different chemotherapy protocol in definitive chemoradiation (Paclitaxel/Oxaloplatin) [33].

On the other hand, Haisley et al., [25] reported better 3-year OS (52\%) and 3-year PFS (44\%), and Rizvi et al., [29], who reported median OS 44 months, and PFS 66 months. This better result is mostly because they studied retrospectively all patients received neoadjuvant chemoradiation followed by surgery.

However, Conroy et al., [21] reported a lower survival rates with a median OS of 20 months (3year OS=27\%), and median PFS of 10 months (3year PFS $=18 \%$ ); the authors suggested that this finding could be indicative of the poor baseline characteristics of the included patients. Noronha et al., [20], also, reported lower survival rates; median OS was 19 months, and median PFS of 11 months; the authors explained that by that only patients with extensive disease are considered for definitive CRT (Stage III patients were 83\%, T4 patients were $53 \%$ ).

Regarding the other prognostic factors affecting the survival; the disease stage was a significant factor affecting both OS and PFS, our results were consistent with Haisley et al., [25] who reported a significant impact of disease stage on survival rates. Another investigators were reported that clinical T4 disease and absence of pathologic complete response were independently associated with inferior overall and disease-free survival [33]

Both chemotherapy regimens used with our patients (Cisplatin/Fluorouracil and Paclitaxel/ Carboplatin) didn't show any differences regarding the tolerability, clinical and pathological response, although non-statistically significant increase in PFS and OS in Paclitaxel/Carboplatin arm. Honing et al., [19] also reported that OS was not different 
between the cisplatin/5-FU and carboplatin/ paclitaxel group. However, Haisley et al., showed a significant difference in pathological response and OS favoring Cisplatin/Fluorouracil over Paclitaxel/Carboplatin, however, they reported a larger number in neoadjuvant setting [25]. Honing et al., was reported significance differences at hematological and nonhematological toxicity (grade 3) in the carboplatin/paclitaxel group (4\% and $18 \%$ ) was significantly lower than in the cisplatin/5-FU (19\% and $38 \%, p=0.001$ ) [19].

In our study the most frequent toxicities were esophagitis (13\%) and neutropenia (24\%). These rates are comparable to that reported by Conroy et al., [21] and Noronha et al., [20] ; esophagitis in $9 \%-12 \%$ and neutropenia in $29 \%-27 \%$, respectively Neutropenia was more frequent when using more toxic agent as reported by Song et al., [32], when they used paclitaxel plus oxaloplatin combined with radiotherapy; as $38 \%$ of their patients developed Grade 3 or more of neutropenia.

As regard the late toxicities; esophageal strictures that required endoscopic dilatation was occurred in $11 \%$ patients, and that is close to Bedenne et al., who reported endoscopic dilatation in $14 \%$ of their patients [22].

We recommended that for patients with resectable Stage II or III esophageal carcinoma and fit for surgery; neoadjuvant chemoradiation followed by surgery is the treatment of choice. For patients with unresectable esophageal carcinoma and/or unfit for surgery; definitive chemoradiation is considered the standard treatment option with accepted outcome. Both chemotherapy regimens (Cisplatin+Fluorouracil or Paclitaxel+Carboplatin) are equally effective with tolerable toxicity profile. So, Cisplatin+Fluorouracil are preferred in our institute for its lower cost, while Paclitaxel+Carboplatin can be reserved for patients with renal impairment in whom Cisplatin is contraindicated.

Further studies are needed to confirm the possibility of omitting surgery after chemoradiation in patients with complete response, especially those with squamous cell carcinoma. Other studies are recommended to evaluate newer chemotherapeutic and targeted agents, and the prognostic factors affecting their efficacy on treatment response and survival rates, in order to improve the outcomes.

\section{References}

1- IBRAHIM A., MIKHAIL N., BARAKA H. and KAMEL H.: Cancer incidence in Egypt: Results of the national population-based cancer registry program. J. Cancer. Epidemiol., 2014.
2- FERLAY J., DIKSHIT R., et al.: Cancer incidence and mortality worldwide: Sources, methods and major patterns in GLOBOCAN 2012. Int. J. Cancer, 136 (5): (Globocan 2012.): E359-E86, 2015.

3- NAPIER K. and MISRA S.: Esophageal cancer: A Review of epidemiology, pathogenesis, staging workup and treatment modalities. World J. Gastrointest. Oncol., 6 (5): 112-20, 2014.

4- STAHL M., STUSCHKE M., LEHMANN N., MEYER H.J., WALZ M.K., SEEBER S., et al.: Chemoradiation with and without surgery in patients with locally advanced squamous cell carcinoma of the esophagus. J. Clin. Oncol., 23 (10): 23 10-7, 2005.

5- BEDENNE L., MICHEL P., BOUCHE O., MILAN C., MARIETTE C., CONROY T., et al.: Chemoradiation followed by surgery compared with chemoradiation alone in squamous cancer of the esophagus: FFCD 9102. J. Clin. Oncol., 25 (10): 1160-8, 2007.

6- NYGAARD K., HAGEN S., SAND H., et al.: Preoperative radiotherapy prolongs survival in operable esophageal carcinoma: A randomized, multicenter study of pre-operative radiotherapy and chemotherapy. The second scandinavian trial in esophageal cancer World $\mathrm{J}$. Surg., 16: 1104-10, 1992.

7- HOFSTETTER W., SWISHER S.G., CORREA A.M., HESS K., PUTNAM J.B., J.R., AJANI J.A., et al.: Treatment outcomes of resected esophageal cancer. Ann. Surg., 236 (3): 376-84; Discussion 84-5, 2002.

8- TEPPER J., KRASNA M.J., NIEDZWIECKI D., HOLLIS D., REED C.E., GOLDBERG R., et al.: Phase III trial of trimodality therapy with cisplatin, fluorouracil, radiotherapy, and surgery compared with surgery alone for esophageal cancer: CALGB 9781. J. Clin. Oncol., 26 (7): 108692, 2008.

9- ALSH T., OONAN N., D. HOLLYWOOD, A. ELLY, et al.: A comparison of multimodal therapy and surgery for esophageal adenocarcinoma. The New England Journal of Medicine, 335 Number 7, 1996.

10- GEBSKI V., BURMEISTER B., SMITHERS B.M., FOO K., ZALCBERG J. and SIMES J.: Survival benefits from neoadjuvant chemoradiotherapy or chemotherapy in oesophageal carcinoma: a meta-analysis. The Lancet Oncology, 8 (3): 226-34, 2007.

11- SJOQUIST K.M., BURMEISTER B.H., SMITHERS B.M., ZALCBERG J.R., SIMES R.J., BARBOUR A., et al.: Survival after neoadjuvant chemotherapy or chemoradiotherapy for resectable oesophageal carcinoma: An updated meta-analysis. The Lancet Oncology, 12 (7): 68192, 2011.

12- GROENE O., CHADWICK G., RILEY S., et al.: Reorganisation of oesophago-gastric cancer services in England and Wales: A follow-up assessment of progress and remaining challenges. BMC Research Notes, 7: 24. doi:10. 1186/1756-0500-7-24, 2014.

13- HERSKOVIC M.K., AL-SARRAF M., LEICHMAN L., BRINDLE J., VAITKEVICIUS V., COOPER J., BYHARDT R., DAVIS L. and EMAMI B.: Combined chemotherapy and radiotherapy compared with radiotherapy alone in patients with cancer of the esophagus. N. Engl. J. Med., 1992. 
14- AL-SARRAF M., MARTZ K., HERSKOVIC A., LEICHMAN L., BRINDLE J.S., VAITKEVICIUS V.K., et al.: Progress report of combined chemoradiotherapy versus radiotherapy alone in patients with esophageal cancer: an intergroup study. J. Clin. Oncol., 15 (1): 277-84, 1997.

15- Neoadjuvant chemoradiotherapy plus surgery versus surgery alone for oesophageal or junctional cancer (CROSS): long-term results of a randomised controlled trial Shapiro, Joel et al.: The Lancet Oncology, Volume 16, Issue 9, 1090-1098, September 2015.

16- MEERTEN E.V., RIJ C.V., TESSELAAR M.E., NEELIS K., RICHEL D., HULSHOF M., et al.: Definitive concurrent chemoradiation (CRT) with weekly paclitaxel and carboplatin for patients (pts) with irresectable esophageal cancer: A phase II study. Journal of Clinical Oncology, 28 (15-Suppl): e14508-e, 2010.

17- MOHAMMAD N., BERGMAN J., GEIJSEN D., WILMINK J., et al.: Acute toxicity of definitive chemoradiation in patients with inoperable or irresectable esophageal carcinoma. BMC Cancer, 14: 56. 2014, 2014.

18- RUPPERT B.N., WATKINS J.M., SHIRAI K., WAHLQUIST A.E., GARRETT-MAYER E., AGUERO E.G., et al.: Cisplatin/Irinotecan versus carboplatin/paclitaxel as definitive chemoradiotherapy for locoregionally advanced esophageal cancer. Am. J. Clin. Oncol., 33 (4): 346-52, 2010.

19- HONING J., SMIT J.K., MUIJS C.T., BURGERHOF J.G., de GROOT J.W., PAARDEKOOPER G., et al.: A comparison of carboplatin and paclitaxel with cisplatinum and 5-fluorouracil in definitive chemoradiation in esophageal cancer patients. Ann. Oncol., 25 (3): 638-43, 2014.

20- NORONHA V., JOSHI A., et al.: Clinical outcome in definitive concurrent chemoradiation with weekly Paclitaxel and Carboplatin for locally advanced esophageal and junctional cancer. Oncology Research, Vol. 23: pp. 183-95, 2016.

21- CONROY T., GALAIS M.P., RAOUL J.L., BOUCHE O., GOURGOU-BOURGADE S., DOUILLARD J.Y., et al.: Definitive chemoradiotherapy with FOLFOX versus fluorouracil and cisplatin in patients with oesophageal cancer (PRODIGE5/ACCORD17): Final results of a randomised, phase 2/3 trial. The Lancet Oncology, 15 (3): 305-14, 2014.

22- BEDENNE L., MICHEL P., BOUCHÉ O., MILAN C., MARIETTE C., CONROY T., et al.: Chemoradiation Followed by Surgery Compared With Chemoradiation Alone in Squamous Cancer of the Esophagus: FFCD 9102. Journal of Clinical Oncology, 25 (10): 1160-8, 2007.

23- FULTON B.A., GRAY J., MCDONALD A., MCINTOSH D., MACLAREN V., HENNESSY A., et al.: Single centre outcomes from definitive chemo-radiotherapy and single modality radiotherapy for locally advanced oesophageal cancer. J. Gastrointest. Oncol., 7 (2): 166-72, 2016.
24- KIM T.J., KIM H.Y., LEE K.W. and KIM M.S.: Multimodality assessment of esophageal cancer: Preoperative staging and monitoring of response to therapy. Radiographics: A review publication of the Radiological Society of North America, Inc., 29 (2): 403-21, 2009.

25- HAISLEY K.R., HART K.D., NABAVIZADEH N., BENSCH K.G., VACCARO G.M., THOMAS C.R.Jr., et al.: Neoadjuvant chemoradiotherapy with concurrent cisplatin/5-fluorouracil is associated with increased pathologic complete response and improved survival compared to carboplatin/paclitaxel in patients with locally advanced esophageal cancer. Diseases of the esophagus: Official journal of the International Society for Diseases of the Esophagus, 30 (7): 1-7, 2017.

26- EL-SAYED M.I.: Chemoradiation Compared to Surgery Alone in Patients With Non-Metastatic Esophageal Carcinoma. Cancer. Clin. Oncol., 4: 4 (1), 2014.

27- VONCKEN F.E.M., VAN DER KAAIJ R.T., SIKORSKA K., VAN WERKHOVEN E., VAN DIEREN J.M., GROOTSCHOLTEN C., et al.: Advanced Age is Not a Contraindication for Treatment With Curative Intent in Esophageal Cancer. Am. J. Clin. Oncol., 2017.

28- ILSON D.H., MINSKY B.D., KU G.Y., RUSCH V., RIZK N., SHAH M., et al.: Phase 2 trial of induction and concurrent chemoradiotherapy with weekly irinotecan and cisplatin followed by surgery for esophageal cancer. Cancer, 118 (11): 2820-7, 2012.

29- RIZVI F.H., SYED A.A., KHATTAK .S, RIZVI S.H., et al.: Complete pathological response after neoadjuvant treatment in locally advanced esophageal cancer predicts long term survival: A retrospective cohort study. International Journal of Surgey, Volume 12, Issue 6, June Pages, 621-625, 2014.

30- STEYERBERG E.W., NEVILLE B.A., KOPPERT L.B., LEMMENS V.E., TILANUS H.W., COEBERGH J.W., et al.: Surgical mortality in patients with esophageal cancer: development and validation of a simple risk score. J. Clin. Oncol., 24 (26): 4277-84, 2006.

31- VELLAYAPPAN B.A., SOON Y.Y., KU G.Y., LEONG C.N., LU J.J. and TEY J.C.S.: Chemoradiotherapy versus chemoradiotherapy plus surgery for esophageal cancer. Cochrane Database of Systematic Reviews Issue, 8. Art No.: CD010511. DOI:10.1002/14651858.CD010511, 2017.

32- SONG T., ZHANG X. and FANG M.: long term result of defintive paclitaxole. Cancer Medicine, 5 (12): 3371-7, 2016.

33- CHEN M-F., CHEN P-T., LU M-S., LEE C-P., CHEN WC.: Survival benefit of surgery to patients with esophageal squamous cell carcinoma. Scientific Reports, 7: 46139. doi:10.1038/srep46139, 2017. 


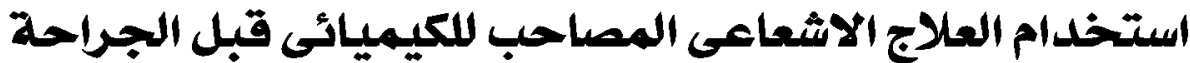

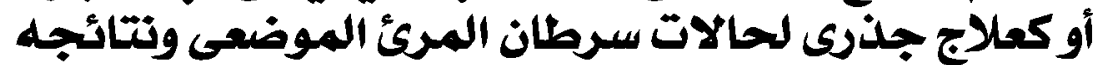 بمعهد جنوب مصر للأورام (دراسة مرئ مرجعية)}

اشتملت هذه الدراسة المرجعية على 0 ه مريضاً بسرطان المرئ المرضعى، تمت معالجتهم بالعلاج الاشعاعى المصاحب اللكيميائى ما

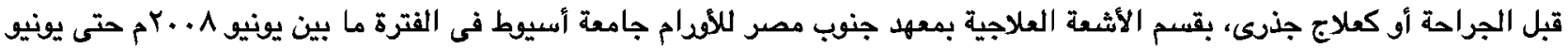
pr.lq

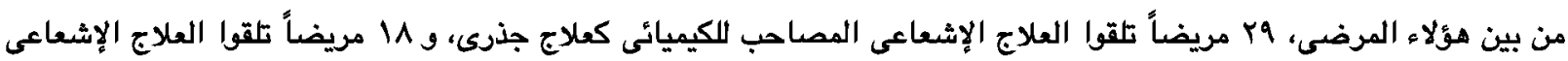
المصاحب اللكيميائى ثم تم الاستئصال الجراحى اللوم ، و 1 مرضى لم يستكملوا العلاج وتم آصائهم من التحليل الإحصائى.

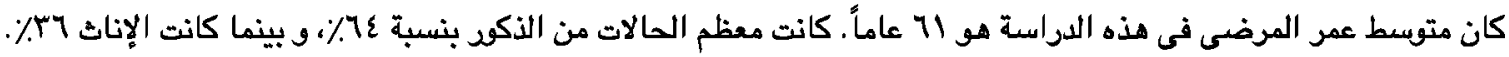
كانت معظم أعراض المرضى وقت التشخيص هى صعوبة فى بلع الطعام (ع ٪) ويليها نقص فى الونن (10٪).

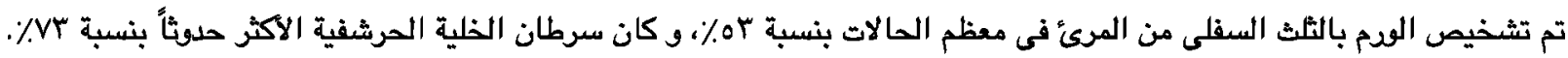

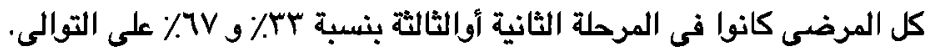

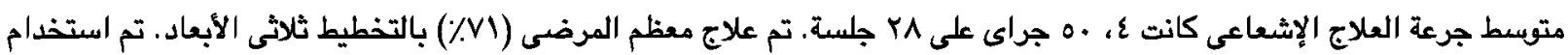

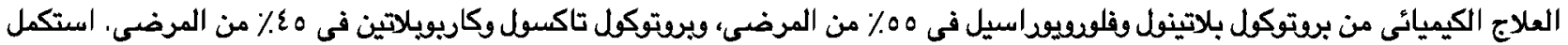

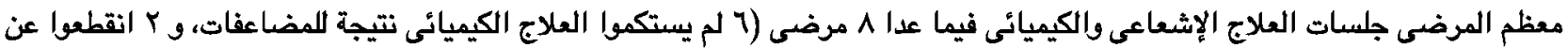

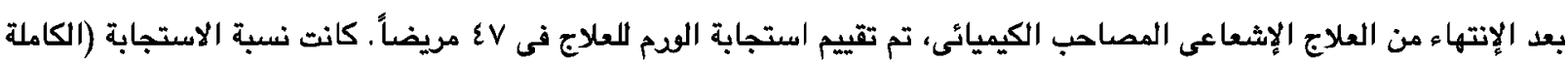

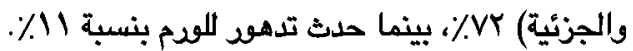

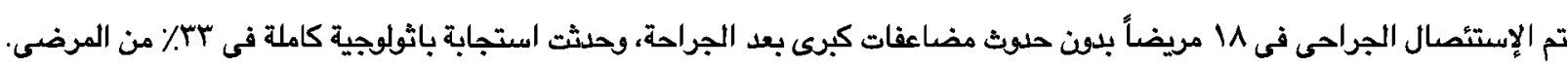

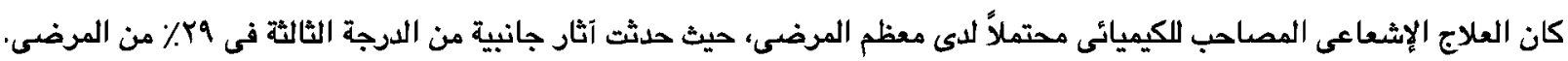
بينما حدثت المضاعفات المزمنة في باهـ من المرضى.

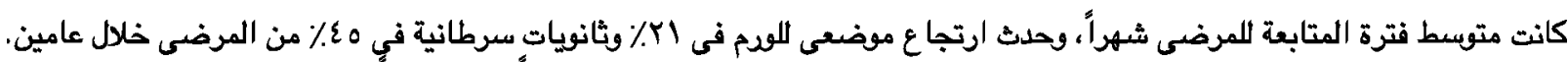

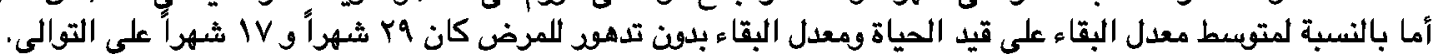

